\section{Call for LINK reform}

\section{London}

THE rules governing LINK, the largest UK government programme supporting industrial/academic collaborative research, should be overhauled, according to the government-appointed committee that oversees the programme.

The independent LINK steering group says that LINK should follow the practice of European Communities research programmes, and allow patents to be owned by whichever research group within a collaboration is responsible for an invention. At present, the Department of Trade and Industry, the government department most closely involved with LINK, prefers patents to be owned by the industrial partners in each LINK project. This is widely believed to have seriously hampered the programme. Bickering over the royalties to be paid to academic researchers in the event of any marketable invention has delayed many research projects.

The steering group's call for reform comes in response to a report from the management consultants Segal Quince Wicksteed (see Nature 351, 178; 16 May 1991), who were asked to examine why many LINK projects have been slow to get off the ground. The government had hoped that $£ \mathbf{4 2 0}$ million would be spent on LINK research between 1988 and 1993, with half coming from government and half from industry. But by November 1990, only 95 research projects, worth a mere $£ 60$ million, were actually under way.

The steering group has rejected several of the consultants' key recommendations, however. Many industrial companies claim that the government pays too little towards the research costs of the industrial partners in LINK projects. The government will pay only half of the total cost of each LINK project. Because academic researchers have their costs met in full, industrial collaborators typically have to cover most of their own research costs. The Segal Quince Wicksteed report suggested paying 35 per cent of companies' costs, to encourage more to take part.

The steering group, however, rejected this idea. Robert Malpas, steering group chairman, does not accept that the level of funding for industrial collaborators is a difficulty. The problem has simply been one of presentation, he says - the government has failed to convince companies of the benefits of collaborating with academic researchers in LINK projects.

The Segal Quince Wicksteed report also fuels the debate over the need for a cabinet minister responsible for science across the whole of government. There is no one person accountable to the cabinet for LINK, the report says. But until there is a minister for science and technology "there is no natural answer to this question."

Peter Aldhous

INDIA

Scientists will miss Gandhi

\section{New Delhi}

Wrrt the assassination of Rajiv Gandhi, Indian scientists have lost a major supporter. Gandhi, the former prime minister who was campaigning to regain that office when he was killed by a bomb, is described by Indian scientists as a politician with a technical mind who wanted to catapult India into the $21 \mathrm{st}$ century.

"With his death, Indian science has lost not just its champion but its very direction," said C. N. R. Rao, chairman of the science advisory council to Gandhi when he was prime minister.

Gandhi inherited a nation with a large scientific infrastructure and manpower, but he believed that Indian scientists were wasting time because their emphasis on selfreliance led them to reinvent the wheel. "He was a man in a hurry," said M. G. K. Menon, who was Gandhi's science adviser for five years. Gandhi, a professional engineer before entering politics, liberalized imports of foreign knowhow and technology, and coaxed Indian scientists to catch up with the West in an atmosphere of competition.

Gandhi took a personal interest in science, Rao said, which set him apart from his mother and predecessor as prime minister, Indira Gandhi, who also promoted science but let other people handle the details. When high-temperature superconductivity became a hot topic, Gandhi set up a commit- tee of scientists with himself as chairman. Three years ago, after becoming impatient with US delays in selling supercomputers to India, Gandhi accepted Rao's proposal to set up a centre for the development of advanced computers. That centre has already delivered its first parallel-processing machine. Gandhi also encouraged the Bhabha Atomic Research Centre to go ahead with its cold fusion work despite criticism.

When India's ASLV rocket crashed in 1987, Gandhi called for a technical presentation by space commission chairman U. R. Rao. Gandhi "grilled [Rao] with questions only a technical man can ask," Menon said.

And after Gandhi introduced a computer policy that lifted import restrictions and spawned local computer companies, India's movement into the computer age noticeably accelerated, said N. Seshagiri, chief of the National Informatics Centre. Seshagiri attributes the commissioning of the centre's computer network, NICNET, to Gandhi, who took a personal interest in it.

Gandhi considered the labyrinthine Indian bureaucracy as the main obstacle to scientific progress, Rao said. Although out of power after the 1989 election, Gandhi was working on a new blueprint for science and technology and a scheme for restructuring the science establishment to free it from the grip of that bureaucracy. K.S. Jayaraman

\section{New Delhi}

A GROWTH in scientific cooperation between India and Australia is expected with the signing of an agreement between the Indian Council of Scientific and Industrial Research (CSIR) and Australia's Department of Industry, Technology and Commerce (DITAC).

Until recently, scientific cooperation between the two countries was at the level of individual scientists. Now, for the first time, CSIR, India's principal scientific agency, will come into close contact with its Australian counterpart, the Commonwealth Scientific and Industrial Research Organization (CSIRO).

Michael Pitman, the DITAC science adviser who recently led a ten-member delegation to India, said there is "substantial scope for increased collaboration involving a wide range of institutions in both countries". The agreement was signed at the conclusion of a ten-day tour by the Australian delegation, which visited more than 20 of India's scientific institutions in order to identify areas of mutual interest.

Under the agreement, India and Australia will exchange scientists, conduct joint workshops and conferences, and carry out joint research projects in certain areas. Marine science and new materials are two that have been given priority. Others are catalysis, molecular biology, food technology, information science and atmospheric physics.

Specific projects for joint research have not yet been worked out, said Barry Filshie of CSIRO's international division, but he offered several possibilities on the basis of discussions so far. The two countries might study new silicon materials for converting sunlight into electricity or the emission of greenhouse gases from paddy fields and cattle sheds. There could also be joint work on scaling up a commercially promising Indian process for converting natural gas into kerosene and diesel fuel. Both India and Australia have surplus natural gas, so "the technology could be of mutual interest," he said.

Indian scientists also expect to try out some unique Australian fodder species for reclaiming saline land, and, according to K. N. Johry of CSIR, Australian dairy scientists are keen on an Indian process for making vegetarian cheese.

Filshie said that DITAC has allocated A $\$ 110,000$ for collaborative projects with India.

K.S. Jayaraman 